NBER WORKING PAPER SERIES

\title{
THE SOCIAL SECURITY RETIREMENT EARNINGS TEST, RETIREMENT AND BENEFIT CLAIMING
}

\author{
Alan L. Gustman \\ Thomas L. Steinmeier \\ Working Paper 10905 \\ http://www.nber.org/papers/w10905
NATIONAL BUREAU OF ECONOMIC RESEARCH 1050 Massachusetts Avenue
Cambridge, MA 02138
November 2004

This paper was supported by a grant from the U.S. Social Security Administration (SSA) to the Michigan Retirement Research Center, UM 04-01, with a subcontract to the National Bureau of Economic Research. The opinions and conclusions are solely those of the authors and should not be construed as representing the opinions or policy of SSA, the Michigan Retirement Research Center, or the National Bureau of Economic Research. Alan L. Gustman is Loren Berry Professor of Economics at Dartmouth College, Department of Economics, Hanover, N.H. 03755 (alan.1.gustman@ dartmouth.edu). Thomas L. Steinmeier is Professor of Economics, Texas Tech University, Department of Economics, Lubbock, Texas 79409 (Thomas.Steinmeier@TTU.edu). The views expressed herein are those of the author(s) and not necessarily those of the National Bureau of Economic Research.

(C) 2004 by Alan L. Gustman and Thomas L. Steinmeier. All rights reserved. Short sections of text, not to exceed two paragraphs, may be quoted without explicit permission provided that full credit, including (C) notice, is given to the source. 
The Social Security Retirement Earnings Test, Retirement and Benefit Claiming Alan L. Gustman and Thomas L. Steinmeier NBER Working Paper No. 10905

November 2004

JEL No. H55, J26, J14, J32, E21, D31, D91, I3

\begin{abstract}
$\underline{\text { ABSTRACT }}$
This paper introduces the age at which Social Security benefits are claimed as an additional outcome in a structural model of retirement and wealth. The model is then used to simulate the effects of abolishing the remainder of the Social Security earnings test, between age 62 and the full retirement age. Estimates are based on data for married men from the first six waves of the Health and Retirement Study.

From age 62 through the full retirement age, the earnings test reduces the share of married men who work full time by about four percentage points, which entails a reduction of about ten percent in the number of married men of that age at full time work. In terms of the cash flow of the system, abolishing the earnings test would have an adverse effect, at least initially. If the earnings test were abolished between the early and full retirement ages, the share of married men claiming Social Security benefits would increase by about 10 percentage points, and the average benefit payments would increase by about $\$ 1,800$ per recipient. The initial increase in benefit payments would eventually be reversed, over a time span of decades, because the annual benefit amounts would eventually be reduced by more than an actuarially fair amount due to the earlier collection of benefits.

One can increase the employment of older persons either by abolishing the earnings test or by increasing the early entitlement age under Social Security. A major difference on the funding side is that abolishing the earning test results in an earlier flow of benefit payments from Social Security, worsening the cash-flow problems of the system, while increasing the early entitlement age delays the flow of benefit payments from the system, improving its liquidity.
\end{abstract}
Alan L. Gustman
Thomas L. Steinmeier
Department of Economics
Department of Economics
Dartmouth College
Texas Tech University
Hanover, NH
Lubbock, TX 79409
and NBER
thomas.steinmeier@ttu.edu
alan.l.gustman@dartmouth.edu 


\title{
"The Social Security Retirement Earnings Test, Retirement and Benefit Claiming"
}

\author{
By Alan L. Gustman and Thomas L. Steinmeier
}

\section{Introduction}

There is a great deal of concern that the looming retirement of the baby boom generation and other demographic changes will adversely affect the solvency of the Social Security system. ${ }^{1}$ In response to this concern, Congress has taken a number of steps to encourage older Americans to postpone their retirement. ${ }^{2}$ Most recently, the Senior Citizens Freedom to Work Act of 2000 (PL 106-182) abolished the Social Security earnings test for those between the full retirement age and 70 years of age. ${ }^{3}$ It is expected that abolishing the earnings test for those between the early and full retirement age would further encourage later retirement. ${ }^{4}$ This is despite the fact that postponing benefits results in increases in future benefits that are, for many individuals, better than actuarially fair. ${ }^{5}$

To understand the effects of abolishing the earnings test for those between 62 and the normal retirement age, one must understand not only how retirement responds to the immediate

\footnotetext{
${ }^{1}$ Trustees Report (2003).

${ }^{2}$ The 1983 amendments contained the most comprehensive of the reforms to encourage later retirement. See Gustman and Steinmeier (1985) for an analysis of the effects of the provisions of this act on retirement outcomes. ${ }^{3}$ Under current Social Security law, benefits are reduced for each year one claims benefits before the full retirement age. This means that for every year benefits are not claimed after age 62 , future benefits are adjusted upward. For example, a person born by January 1, 1938, who has a full retirement age of 65 , would receive 80 percent of full benefits upon retiring at age 62 . Therefore, postponing benefit receipt until age 63 would increase yearly benefits by 8.38 percent $(.067 / .8)$ for the rest of his life. The earnings test has a similar effect. For those between ages entitling them to early and full benefits, the Social Security earnings test reduces benefits received by fifty cents for every dollar earned over the exempt amount $(\$ 11,520$ in 2003). A person expecting a yearly Social Security pension of $\$ 10,000$ at age 62 would find the entire benefit reduced to zero if earnings reached $\$ 31,520$. Benefits lost to the earnings test are restored in future years, again at a rate that for many is better than on an actuarially fair basis. ${ }^{4}$ For those born in 1937 or earlier, who attained age 62 by 1999, the full retirement age is 65 . The full retirement age is then increased two months per year until reaching 66 for those born in 1943, staying at 66 between 1943 and 1954, and increasing in two month increments per year of birth between 1955 and 1960, where it reaches age 67.

5 At a 3 percent real interest rate, and for many taking into account the effect of postponing own benefits on benefits paid to their spouse, given current life tables this adjustment is better than actuarially fair (Gordon and Blinder, 1980; Feldstein and Samwick, 1992).
} 
reward for work against the benefit payments that would be received should the person retire, but how different people in the population value the increased benefit payments in future years that are paid when one postpones retirement. The valuation of the tradeoff between current and future benefit payments may not be determined by the market interest rate alone. A person with a high rate of time preference and no ability to borrow at the lower rate said to obtain in the market will discount future benefit adjustments more heavily than the market rate suggests.

Another implication of high time preference is that many of those who have left the labor force before reaching age 62 will choose to claim their Social Security benefits immediately, even though they would benefit actuarially from deferring their claim to a later age, and they are free to do so. Early claiming is not as evident among those who continue to work after age 62 as it is among those who have retired by age 62. A person who would lose a substantial amount of benefits to the earnings test may find it inconvenient to simply postpone benefit acceptance rather than accept benefits and then have a major portion or the full benefit taken away by the earnings test. More importantly, a person who loses benefits to the earnings test has to wait until "the roundup calculation" at full normal retirement age to have those lost benefits begin to be reflected in a higher benefit payment stream, even if the person retires before reaching normal retirement age. However, a person who delays registering for Social Security benefits will enjoy an immediate benefit increase once the person registers for benefits. Given claiming behavior by those who have retired before age 62 , it is reasonable to expect that were the earnings test abolished, even more covered workers, especially full time workers, would claim their benefits at the Social Security early entitlement age.

This paper investigates the likely effect on work and benefit claiming of abolishing the retirement earnings test between the ages of 62 and full retirement. It uses data from the first six 
waves of the Health and Retirement Study to estimate a structural model of retirement and saving in which the person explicitly chooses when to claim Social Security benefits. ${ }^{6}$ This model is then used to simulate the effects of eliminating the retirement earnings test.

There are many advantages to using a structural model to analyze the effects of abolishing the earnings test. The structural model we specify includes a myriad of factors that influence retirement behavior. Also, we explicitly model claiming behavior, an aspect of behavior that has not been included in studies of the effects of earnings test on retirement. Moreover, a structural model is capable of estimating behavioral responses in the long term. Studies that base estimates on natural experiments are unlikely to reflect the full labor supply adjustment to the change in incentives. For example, the decision to return to full employment once having retired is not the same as the decision to delay leaving a full time job for a few more months or years. Thus were the earnings test abolished, fewer would return to full employment from retirement, a short run response, than would be willing to stay longer in their main job, a long run response. ${ }^{7}$ Some within a couple of years of retiring at the time the earnings test is abolished will have accumulated additional saving to finance an early exit from the market.

On the other hand, the weakness of using a structural retirement approach is that the findings are conditional on the model having been well enough specified that omitted or misspecified factors are not driving important outcomes. Reduced form models are also sensitive to omitted factors, and although in one sense they are less sensitive to precise structural assumptions, they face the difficulty of separating program effects from unmeasured individual

\footnotetext{
${ }^{6}$ The Health and Retirement Study is supported by the National Institute on Aging, and also benefits from support by the Social Security Administration.

${ }^{7}$ Studies of the effects of abolishing the earnings test rely either on changes in the earnings test kink point (Friedberg, 2000), or on the observed change in employment patterns between workers affected by the abolition of the earnings test and those who were not. Disney and Smith (2002) examine the effects of the abolition of the earnings test in Britain. Song (2002) and Tran (2002) examine the effects of abolishing the earnings test for those over the normal retirement age in the U.S.
} 
characteristics such as taste parameters, which does require a good understanding of the underlying structure.

Abolishing the earnings test is simulated by allowing immediate benefit claiming between the early and full retirement age without reducing benefits in accordance with a person's earnings. For those who have a high discount rate, there will be an interaction between the earnings test, benefit claiming and retirement. Because benefits can be claimed immediately, the opportunity cost of continued work is reduced. Before the abolition of the earnings test, the current benefit is lost, and the increase in future benefits is inadequate to compensate, so the individual with a high discount rate may choose to retire. After the earnings test is abolished, the same individual will be able to continue at work without having to forego the benefit payment, and so may choose to stay at work. The resulting changes in full-time and part-time work among other things depend on the distributions of time and leisure preference, as well as the opportunity set, all of which are estimated by the model.

Abolishing the earnings test is not the only way that Social Security might be changed to encourage later retirement. Gustman and Steinmeier (2004a) show that increasing the age of entitlement to early benefits would substantially increase the age of retirement. ${ }^{8}$ It is useful to compare the effects of increasing the early entitlement age to 64 with the effects of abolishing the earnings test. This is not only of interest because both policies will encourage later retirement, but also because the two policies have very different implications for the solvency of the Social Security system. Increasing the early entitlement age will delay the payment of any benefits, while abolishing the retirement earnings test will accelerate the pace of benefit

\footnotetext{
${ }^{8}$ Gustman and Steinmeier (2003) show that certain other changes in Social Security, such as proposals by the President's Commission to Strengthen Social Security that would raise the actuarial reward to continued work, would also reduce retirement rates.
} 
payments, increasing the cash flow problems of the system. We estimate the sizes of the effects of these two policies both with respect to the age of retirement and with regard to the flow of funds to and from the Social Security system.

Section II of the paper briefly reviews the literature on the retirement earnings test. Descriptive statistics are presented in Section III. A structural model of retirement and saving is described in Section IV. Estimates of the model are presented in Section V and their implications are discussed. Section VI uses the model to simulate the effects of abolishing the retirement earnings test between ages 62 and the age of eligibility for full retirement benefits. Section VII compares the effects of abolishing the retirement earnings test with the effects of increasing the early entitlement age to 64 , focusing on the flow of Social Security benefits. Section VIII concludes.

\section{Previous findings.}

In a conventional model of retirement, the earnings test is the intervening mechanism that, for many, links Social Security benefits and benefit claiming to the retirement decision. Social Security also affects retirement because additional work is likely to increase the average wage on which benefits are computed (the recomputation effect) and because many individuals do not have sufficient savings to allow them to retire before Social Security benefits become available. But many individuals see the earnings test effectively as a tax on continued work, and the tax is of such a magnitude that it provides a strong incentive to retire, or at least not to work so much as to be subject to the tax.

Although policy analysts are well aware of the relation of the earnings test to the timing of benefit claiming (Gruber and Orzag, 1999), empirical studies of the role of the earnings test have not focused on its implications for the timing of benefit claiming. Rather, much of the 
discussion of the earnings test has focused on the labor market behavior of those who are collecting benefits. In particular, it has long been recognized that many people who are collecting Social Security benefits, but who work part time, stop working when their earnings just reach the annual exempt amount (Gordon and Blinder, 1980; Burtless and Moffitt, 1984).

One common argument made to explain the bunching of earnings at the annual exempt amount is that people do not understand that benefits lost to the earnings test will be restored in later years. In this paper we will focus on another possible answer, both for the prevalence of early claiming and for the spike in earnings at the exempt amount. Our focus is on the role of heterogeneity in time preference rates, and the effects of high real discount rates on the timing of benefit claiming. Evidence suggests that high time preference rates affect saving (Samwick, 1998), and that high time preference also accounts for the peak in retirement activities at age 62 (Gustman and Steinmeier, 2002 and 2004b). Heterogeneity in time preference rates may also explain the prevalence of benefit claiming at the early entitlement age, a phenomenon that researchers have had difficulty explaining (Coile et al., 2002). ${ }^{9}$ More specifically, assets held by high discounters in the years just preceding retirement may be low enough that the time preference rate also governs the rate at which future benefits are discounted. Accordingly, even though the Social Security system restores benefits lost to the earnings test at what the market considers to be a better than actuarially fair rate, high discounters may not deem the adjustments to be actuarially fair. These same high discounters may also be disinclined to postpone benefit claiming. Given the favorable actuarial rate offered by Social Security, they should delay their claiming of benefits for a year or more after age 62. Yet as we will see, most do not.

\section{Descriptive data on the earnings test and benefit claiming.}

\footnotetext{
${ }^{9}$ Friedberg (2000) produces a reduced form analysis of the retirement earnings test. Her analysis falls silent on the question of benefit acceptance and the wide distributions of time preferences that characterize the population.
} 
Table 1 shows that data from the 1992-2002 waves of the Health and Retirement Study (HRS) duplicate the findings from earlier studies regarding the bunching of work effort around the earnings test limit. For example, consider those who are partially retired. ${ }^{10}$ As seen in the middle panel, grouping partially retired respondents by their earning bracket, and using brackets defined in ten percentage point intervals, the brackets from 50 percent to 100 percent of the earnings test amount each contain 7 percent to 9 percent of the 62 to 69 year olds in the survey. Each bracket from 110 percent to 150 percent of the earnings test amount contains 1 percent to 3 percent of the population.

In the year 2000 the earnings test was abolished for those over age 65, and it should be possible to see if this had any effect on work. Table 2 presents data for full-time work by HRS respondents in the survey years 1996, 1998, 2000, and 2002. Since 2000 was the year the earnings test was abolished, and there was some confusion in that year, we can compare 2002, after the test was abolished, with 1998, before the test was abolished. The next to the last column calculates the difference in the percentages between 2002 and 1998. For instance, 32.7\% of 62 year olds were working in 2002, compared to $29.4 \%$ in 1998, for an increase of 3.3 percentage points. For 65-67 year olds, for whom the test was abolished, the increase in fulltime work was 3.1 percentage points, while for 62-64 year olds, for whom the test remained in effect, the increase in full-time work was 2.8 percentage points. By this metric, it appears that abolishing the test for those over 65 did not have much of an effect, since they behaved very similarly to those under 65 , for whom the test was not abolished.

\footnotetext{
${ }^{10}$ Full time workers are defined as those working more than 30 hours per week and more than 1560 hours per year. Those who are partially retired are working more than 100 hours per year but less than 25 hours per week. Individuals who fall between full-time and partial retirement, or between partial retirement and complete retirement, are classified on the basis of self reports. This means, for instance, that a teacher working 36 weeks at 35 hours per week (1260 total hours per year) would be counted as full-time if the self reported retirement status was "not retired at all."
} 
However, this approach ignores the fact that there were many fewer individuals working at ages $65-67$, so the percentage point changes come from a much smaller base in that age range. The final column of Table 2 presents the ratio of the 2002 full-time workers to the 1998 full-time workers. For 62-64 year olds, the rate of full-time work increased by about 11 percent, while for 65-67 year olds it increased by about 22 percent. By this measure, abolishing the earnings test had a non-trivial effect, since the increase in full-time work was greater for those for whom the test was eliminated than for those for whom it remained in effect.

Table 3 reports the fractions of men and women respectively who have claimed Social Security benefits by age and retirement status. ${ }^{11}$ These HRS data illustrate the well known tendency of people to claim benefits as soon as they retire. Except for the transition year at age 62 , more than four fifths of retirees from full time work collect benefits at each year of age. The modest increase in the share of the full population claiming benefits reflects both a modest increase in claiming rates with age within each retirement category, and the increasing share of the population having left full time work with each year of age.

\section{A Structural Model of Retirement, Saving, and Benefit Claiming}

\section{A. The Model.}

The model is an extension of a structural, dynamic model of retirement and saving that we have developed in previous work. ${ }^{12}$ The extension is that in this model individuals can choose optimally when to register for Social Security benefits. The model specifies a lifetime

\footnotetext{
${ }^{11}$ The later structural analysis excludes observations for women. Gustman and Steinmeier (2004c) estimates a model of joint family retirement in an environment where one cannot borrow on future pensions and Social Security. However, that model does not include partial retirement. In the model estimated in this paper, the husband values the wife's income and spouse and survivor benefits, but in two earner families, the wife's earnings are exogenous.

${ }^{12}$ We have used the model for policy analysis, in one case simulating the effects of raising the Social Security early entitlement age (Gustman and Steinmeier, 2004a) and in another, simulating certain proposals made by the President's Commission to Strengthen Social Security (Gustman and Steinmeier, 2003). A full description of the methodology in estimating the model and using it to simulate policy is found in our earlier work.
} 
expected utility function with the time path of consumption and leisure as arguments. The constraints include an asset accumulation equation and an uncertain lifetime.

Workers are allowed to partially retire, usually in different jobs from those held in prime working age. As a result, work when partially retired typically pays a lower wage rate. Social Security enters as income in the asset accumulation equation in the years that benefits are received. The current utility value of the future benefits is, of course, heavily dependent on the worker's time preference rate. Retirement preferences and time preferences are both allowed to be heterogeneous among workers.

The utility function is given by

$$
\mathrm{U}=\sum_{\mathrm{t}=0}^{\mathrm{T}}\left\{\mathrm{e}^{-\rho \mathrm{t}} \sum_{\mathrm{m}=1}^{3}\left[\mathrm{~s}_{\mathrm{m}, \mathrm{t}}\left(\frac{1}{\alpha} \mathrm{C}_{\mathrm{m}, \mathrm{t}}^{\alpha}+\mathrm{e}^{\mathrm{X}_{\mathrm{t}} \beta+\varepsilon} \frac{1}{\gamma} \mathrm{L}_{\mathrm{m}, \mathrm{t}}^{\gamma}\right)\right]\right\} \quad \alpha, \gamma<1
$$

In this equation, $\mathrm{T}$ is the maximum lifespan and $\mathrm{m}$ refers to the family structure at time $\mathrm{t}$ (both spouses alive, only the husband alive, or only the wife alive). $\mathrm{s}_{\mathrm{m}, \mathrm{t}}$ is the probability of family structure $\mathrm{m}$ at time $\mathrm{t}, \mathrm{C}$ is consumption, and $\mathrm{L}$ is the leisure, which takes on a value of 0 for full-time work, 1 for full retirement, and $1 / 2$ for partial retirement. ${ }^{13} \mathrm{X}$ includes a constant, age, health status, and vintage. The age variable in $\mathrm{X}$ causes leisure to become gradually more attractive as the individual ages, reflecting the gradual wear and tear which makes the rigors of work relatively less attractive. As the value of leisure increases for this reason and perhaps also because of worsening health, at some point the utility of leisure surpasses the utility of the consumption that continued work makes possible, and the individual retires. It is important to note explicitly that $\mathrm{X}$ does not contain any binary age variables or

\footnotetext{
${ }^{13}$ In recognition that consumption is more valuable while both spouses are alive, the consumption function is adjusted so that the marginal utility for a surviving spouse is approximately equal to that for a couple consuming $40 \%$ more.
} 
splines in age which might encourage retirement at a particular age.

The preferences allow for three types of heterogeneity. The time preference term $\rho$ is a fixed effect, and the leisure preference term $\varepsilon$ is a random effect drawn from a normal distribution. The parameter $\gamma$, which governs how desirable partial retirement is relative to full retirement or full-time work, is also random effect. It is taken so that the term $(1 / 2)^{\gamma}$ comes from the exponential distribution $\mathrm{f}\left[(1 / 2)^{\gamma}\right]=\mathrm{ke}^{\delta(1 / 2)^{\gamma}}$ defined over $(1 / 2)^{\gamma} \in[1 / 2,1]$, which is the theoretically acceptable range of $(1 / 2)^{\gamma}$ for $\gamma \in[0,1]$. $\mathrm{k}$ is the constant necessary for the density function to integrate to unity, as it must. Since partial retirement seems to become relatively more attractive as the individuals age, we specify $\delta$ to be increasing in age: $\delta=\delta_{\mathrm{o}}+$ $\delta_{\mathrm{a}} \times$ Age.

The asset accumulation over time is given by

$$
A_{m, t}=(1+r) A_{m, t-1}+W_{m, t}\left(1-L_{m, t}\right)+E_{m, t}+B_{m, t}-C_{m, t}, \quad \text { with } A_{m, t} \geq 0
$$

where $A_{m, t}$ is the level of real assets at time $t$ in survival state $m, r$ is the real interest rate, $\mathrm{W}_{\mathrm{m}, \mathrm{t}}$ is the real wage rate, $\mathrm{E}_{\mathrm{m}, \mathrm{t}}$ is the earnings of the spouse, and $\mathrm{B}_{\mathrm{m}, \mathrm{t}}$ is the level of Social Security and/or pension benefits at time t. The equation must hold for any legitimate transition between survival state $\mathrm{m}$ at time $\mathrm{t}-1$ and survival state $\mathrm{m}$ at time $\mathrm{t}$. If the individual is working, the wage rate may depend on whether the work is full-time or part-time. The earnings and pension benefits of the spouse are treated as exogenous in this paper.

The level of benefits $B_{m, t}$ at time $t$ depends on the previous decisions of the individual as to when to leave full-time employment and when to retire fully, as well as the current survival state. It also depends on the decision of the individual as to when to apply for Social Security benefits; obviously, no benefits can be paid until the individual has applied for them. This means 
that a delay in the application will result in increased benefits later. Note that this model does not calculate the value of accruals to Social Security and pensions directly, but the value of the accruals is implicit in the model because work during one period will affect the value of Social Security and pension benefits in later periods. The implicit value of these accruals, of course, depends strongly on the time preference rate.

The model has 8 parameters to be estimated. These include the consumption parameter $\alpha$, four elements of $\beta$ including the constant and coefficients for age, poor health, and birth year, two elements of $\delta$ including a constant and a coefficient of age, and the standard deviation of retirement preferences given by $\sigma_{\varepsilon}$.

\section{B. Estimation.}

Estimation is based on the general method of simulated moments. ${ }^{14}$ The calculation of the simulated moments follows from the following decomposition of the utility function:

$$
U=\left[\sum_{t=0}^{T} \sum_{m=1}^{3}\left(e^{-\rho t} s_{m, t} \frac{1}{\alpha} C_{m, t}^{\alpha}\right)\right]+\left[\sum_{t=0}^{T} \sum_{m=1}^{3}\left(e^{-\rho t} s_{m, t} e^{X_{t} \beta} \frac{1}{\gamma} L_{m, t}^{\gamma}\right)\right] e^{\varepsilon}
$$

A crucial observation is that the first part of the utility function does not depend on the random effects $\varepsilon$ and $\gamma$, and the second part does not depend on consumption or the budget set. For all possible combinations of partial and full retirement ages, and for all possible ages for initial Social Security claims, the budget set is calculated. Given the budget set, and given values of $\alpha$ and $\rho$, optimal consumption is calculated by solving the dynamic programming model. The associated utility of the optimal consumption stream is $U_{C}\left(r_{1}, r_{2}, a ; \alpha, \rho\right)$, where $r_{1}$ is the age of partial retirement, $r_{2}$ is the age of full retirement, and a is the claiming age. If there is no partial retirement, $r_{1}=r_{2}$. The optimal claiming behavior for particular values of $r_{1}$ and $r_{2}$ is

\footnotetext{
${ }^{14}$ For a more detailed description, see Greene (2000).
} 
just the value of a which maximizes $U_{C}: U_{C}\left(r_{1}, r_{2} ; \alpha, \rho\right)=\max _{a} U_{C}\left(r_{1}, r_{2}, a ; \alpha, \rho\right)$.

Next, 10,000 random values of $\varepsilon$ and $\gamma$ are chosen, and for each set the value of the second part of the utility function is evaluated for each combination of $r_{1}$ and $r_{2}$. This utility depends on the retirement dates and the value of $\beta$ : $U_{L}\left(r_{1}, r_{2} ; \varepsilon, \gamma, \beta, \rho\right)$. Note that the calculation of $U_{L}$ does not require the solution of a dynamic programming model and hence can be done quickly. For each set of $\varepsilon$ and $\gamma$, the total utility is evaluated for each set of retirement dates $r_{1}$ and $r_{2}$, and the retirement dates are the ones which maximize the total utility: $\mathrm{U}(\varepsilon, \gamma, \rho ; \alpha, \beta)=\max _{\mathrm{r}_{1}, \mathrm{r}_{2}} \mathrm{U}_{\mathrm{C}}\left(\mathrm{r}_{1}, \mathrm{r}_{2} ; \alpha, \rho\right)+\mathrm{U}_{\mathrm{L}}\left(\mathrm{r}_{1}, \mathrm{r}_{2} ; \varepsilon, \gamma, \beta, \rho\right)$. Thus, given $\rho$ and values for the parameters $\alpha$ and $\beta$, the distribution of retirement ages is built up from the 10,000 values of $\varepsilon$ and $\gamma$.

The next issue is: where do we get the value for the fixed effect $\rho$ ? To resolve this, we use the actual retirement dates (if retirement occurs within the sample) or the expected retirement dates (if it does not). Given a value of $\alpha$, we then pick a value of $\rho$ and solve the consumption problem described above. Using the optimal consumption values and the asset accumulation equation, we can solve for assets at the beginning of the sample period, which is 1992 for the HRS. If these assets are larger than the assets actually observed, we adjust $\rho$ upward; otherwise we adjust $\rho$ downward. The fixed effect is the value of $\rho$ for which the calculated accumulation just matches the actual assets. Note that this fixed value depends on the value of $\alpha$ and so must be recalculated each time the estimation procedure considers a new value of $\alpha$.

For a given set of parameters, these simulations give simulated sample moments. In the generalized method of simulated moments, these simulated sample moments are compared to the actual sample moments, and the procedure adjusts the parameters to minimize the differences 
between the simulated moments and the actual moments. In the minimization, the moments are weighted so as to provide the most precise estimates possible with the data. 13 of the moments used in the estimates are the retirement rates from full-time work for each age between 54 and 66. The remaining moments are calculated at ages 55, 58, 60, 62 and 65 and include the rates of retirement from full-time work for those in poor health, for those in the upper third of the income distribution, for those in the lower third of the income distribution, for those born before 1934, and for those born after 1938, and the rates of full retirement for those in poor health.

The simulations proceed in almost exactly the same manner as the estimates, except that only the estimated values of the parameters need be considered. Tallies can be made for almost any aspect of the model, including the percentages fully retired and partially retired at different ages, the percentage claiming Social Security benefits, the distribution of time preference rates, and the amount of Social Security taxes and benefits by age. Simulations of hypothetical alternatives are accomplished by simply making the appropriate changes in the budget sets and simulating the results.

\section{Data used in the model estimation.}

The model is estimated for married men who are career workers from the original cohorts of the Health and Retirement Study, using observations from the first six waves of the survey, every other year from 1992 through 2002. The selection of the sample, and reasons for deleting observations, are reported in Appendix Table 1. The definition of retirement in this study is a hybrid one relying both on objective and subjective measures as described in footnote 10 .

Earnings profiles are taken from Social Security records or, if these are not available, from the retrospective information in the respondent surveys. Future potential earnings are projected on the basis of tenure and experience coefficients of earnings regressions. Pension 
benefits, conditional on tenure in the job providing the pension, are based on information in the summary pension descriptions, provided by the employers. Social Security benefits are based on the earnings histories and figured according to the Social Security rules.

\section{Model estimates and implications.}

\section{A. Actual retirement outcomes.}

Table 4 presents the basic descriptive data on retirement outcomes by age in the HRS. As is well known, in recent years, the spike in retirement occurs around the age of early entitlement to Social Security benefits, age 62. Roughly 15 percent of the relevant sample of males retires at age 62, about 9 percent more than those retiring in surrounding years. About 9 percent of the population retires from full time work at age 65 , about 3.5 percent more than those retiring in neighboring years. Note that these percentages are percentages of the population retiring at different ages, not the hazard rates for retirement at particular ages.

\section{B. Parameter estimates.}

Table 5 presents the results of the parameter estimates. All of the key parameters except the coefficient on the measure of vintage are significant at conventional levels. An indication of the ability of the model to fit the data can be seen by comparing the baseline simulations of the retirement outcomes at different ages in Table 6, and simulations of benefit claiming by age in Table 7, with the descriptive data in Tables 4 and 3 respectively.

Comparing the retirement rates from full time work reported in column 1 of Table 6 , which contains the baseline simulation results, with the observed retirement rates in Table 4 above, the simulations catch most but not all of the spike in retirements at age 62 , where 13.1 percent of the population is simulated to retire from full time work, 7.5 percent above the values in surrounding years, while the population figures, 15.1 percent retire at age 62,9 percent more 
than in surrounding years as noted above. At 65 the actual spike in retirements from full time work is 9.1 percent, while the simulations generate a peak of 5.9 percent, only 1 percent higher than in surrounding years. So the simulations do less well at the normal retirement age. With regard to the numbers completely retiring from the labor force, the simulations catch 9.4 percent out of the 12.5 percent found to retire in the raw data at age 62 , and 5.6 percent out of 6.7 percent at age 65 .

The model tracks the fraction of the population claiming Social Security benefits between ages 62 and 65 fairly well, understating claiming behavior on average by a modest amount, and missing the mark most severely at age 63 . This can be seen by comparing the baseline projections of the percent of the full sample of married men collecting Social Security benefits in Table 7 with the actual percentages of married men claiming benefits by age as reported in Table 3. According to the last column of Table 3, 47.5 percent of all married men claim their benefits at age 62. The last column of Table 7 projects a claiming rate of 41.3 percent at age 62 . While the claiming rate at age 62 is affected by the fact that it is a transition year (see Olson, 1999), the projected claiming rate for the full sample at age 63 is 48.1 percent, compared to an actual claiming rate of 61.7 percent. For ages 64 and 65, the claiming rates are 68.4 and 84.6 percent, while the projected claiming rates are 60.1 percent at age 64, and 84.7 percent at age 65. Again it is at age 63 that the projected claiming behavior falls furthest below the mark.

Tables 3 and 7 also project the claiming rate conditional on retirement status. For example, from Table 3, first column, the actual claiming rates for those who have left full time work are 72.0, 83.7 and 86.1 percent for those 62,63 and 64 respectively, while from the first column in Table 7, the projections are 59.9, 65.1 and 77.1 percent respectively.

\section{Simulations of the effects of abolishing the retirement earnings test between 62 and full}




\section{retirement age.}

In this section we use the model in which people are free to choose when to claim their benefits to simulate the effects of abolishing the earnings test. This affects all respondents before age 65 and, for a substantial fraction of the sample, respondents who had already reached age 65 before the year 2000. Outcomes simulated include the effects of the earnings test on full and partial retirement and benefit claiming.

\section{A. Implications for retirement outcomes.}

Table 8 reports the differences in retirement outcomes between a simulation in which the earnings test is eliminated and the baseline results in Table 6. There are two notable effects on retirement from abolishing the earnings test. As seen in the next to last column, from ages 62 to 65 , the percentage retired from full time work is reduced by about four percentage points per year. With less than half the labor force still at full time work, this entails an increase of about ten percent in full time work by that population.

Some of those who remain at full time work came from the ranks of the partially retired. As a result, there is a much smaller effect on the fraction of the labor force that is completely retired, ranging between a 1 and 2 percentage point decrease.

Notice the effect on the retirement spike at age 62 from abolishing the earnings test. The earnings test creates a link between the reward to work from continuing at full time employment and the desire to claim Social Security benefits at age 62 for those with a high discount rate or low actuarial reward to postponed benefit receipt. This link encourages 3.8 percent of the population to retire at age 62 who would not otherwise retire if that link were not there. Therefore abolishing the earnings test would reduce the spike in retirements at age 62 by about 3.8 percentage points. 
One other finding should be noted. In these simulations, abolishing the earnings test between early and full retirement age increases by 2 to 3 percentage points the fraction at full time work throughout the age range from 66 to 69 . There are two reasons for this finding. First, a number of those in the sample were born too soon to benefit from the abolition of the earnings test for those over the age of 65 in 2000. Second, others in the sample who were born in later years are facing an age 66 age of entitlement for full benefits.

\section{B. Implications for the percent collecting Social Security benefits by age and the flow of Social} Security benefits and taxes.

Table 9 projects the likely effect of abolishing the retirement earnings test on benefit claiming. The increase in claiming by the population ages 62 to 64, seen in the last column of Table 9, is ten to thirteen percent of the sample. By far the bulk of the increase in benefit payments are projected to come from the ranks of those holding full time jobs, with 20 to 40 percent of persons remaining at full time work claiming benefits at each year of age between 62 and 64 should the earnings test be abolished, with claiming increased through the age of 69 .

Table 10 details the changes in Social Security taxes paid and benefits received between simulations with and without the earnings test. Both taxes and benefits are weighted by the probability the individual survives to pay or collect them. The changes in Social Security taxes paid and benefits received are dependent both on changes in claiming behavior and on changes in employment induced by the removal of the earnings test. For those between the ages of 62 and 66, benefits are increased substantially after the abolition of the earnings test, ranging from $\$ 1,000$ to $\$ 2,300$ in additional benefits at each year of age. To attain actuarial balance, from age 70 onward, benefits are substantially reduced. Thus the abolition of the earnings test accelerates benefit payments by the Social Security Administration forward, and although reclaimed from a 
generation within the span of its lifetime, these payments are not reclaimed for the system for many years. That is, because the system is actuarially fair or more than actuarially fair, there is no loss to the system in present value terms from abolishing the earnings test, and perhaps even a small gain over the individual's lifetime. However, by the time the accelerated payments made to the first generation are recaptured, younger cohorts will be enjoying accelerated payments. Thus the system will take a hit to its liquidity on a one time basis that in a simple steady state would perhaps never be offset.

\section{Abolish the retirement earnings test or raise the early entitlement age to 64?}

In an earlier paper we have examined the effects of increasing the early entitlement age for Social Security benefits from 62 to 64 (Gustman and Steinmeier, 2004a). This is a policy that we expect to have similar effects on retirement as eliminating the earnings test between early and full retirement age. But we also expect raising the early entitlement age to have a more favorable effect on the liquidity of Social Security finances. ${ }^{15}$

\section{A. Implications for retirement outcomes.}

Column 3 of Table 11 indicates that increasing the early entitlement age to 64 , leaving the earning test in place, would reduce the ranks of those retired from full time work by over 7 percentage points at ages 62 and 63 . In contrast, Table 8 suggested that eliminating the earnings test would reduce the ranks of the retired by about 4 percentage points at each year of age from 62 to 66 , and by a smaller amount at older ages. Counting the labor market effects after age 66 ,

\footnotetext{
${ }^{15}$ Gruber and Orzag (1999) suggest that eliminating the earnings test will have unfavorable effects on the distribution of benefits because those who claim their benefits early are left with lower benefits in later years, and those with lower lifetime earnings are more likely to claim their benefits early. Indeed, one consideration that mitigated against eliminating the earnings test between early and full retirement age in 2000 was the specter of poor widows whose low benefits reflected the fact that their husband's elected to receive benefits early. Gruber and Orzag provide relevant descriptive numbers. They also note that the earnings test may favor high income individuals if their life expectancy is longer than those who are entitled to lower benefits. In the latter case, abolishing the earnings test may have a progressive impact on the distribution of benefits paid over the lifetime.
} 
eliminating the earnings test appears to have a more powerful effect on the percentage at full time work, primarily due to the fact that the earnings test still affected many in the HRS sample who turned 65 before the year 2000. On the other hand, raising the early entitlement age appears to have a larger effect on the rolls of those who are completely retired.

These differences can be readily seen in Table 12. Entries in this table are the differences in retirement outcomes between a regime with an early entitlement age of 64 vs. a regime with no earnings test. For instance, at age 65 eliminating the earnings test would decrease the percentage retired from full time work (increase full-time work) by 4.2 percentage points, as indicated in the third column of Table 8. At the same age, changing the early entitlement age would decrease the percentage retired from full time work (increase full-time work) by 0.4 percentage points, as indicated in the third column of Table 11. The difference between these two scenarios is 3.8 percentage points, as indicated in the third column of Table 12.

\section{B. Implications for benefit claiming.}

Table 13 shows the strong and obvious effect on benefit claiming of raising the early entitlement age to 64 . Table 14 shows the difference in benefit claiming between two regimes, the first where the early entitlement age is increased to age 64, and the second where the earnings test is abolished. This table is the difference between the entries in Table 13 and the corresponding entries in Table 9, with negative numbers indicating that benefit claiming is higher if the earnings test is eliminated than if the early entitlement age is increased. From the last column in Tables 13 and 14, we see that raising the early entitlement age to 64 would reduce the overall claiming by more than 40 percentage points at ages 62 and 63, and by more than 50 percentage points as compared to a scenario where the earnings test is eliminated. In Table 14, the numbers continue to be negative after age 64 , largely because the elimination of the earnings 
test increases benefit claiming by those who remain at full time work.

\section{Implications for the flow of taxes and benefits.}

Tables 15 and 16 indicate the differences in the flows of Social Security taxes and benefits for the comparable two cases. In Table 15, we see the effect of increasing the age of early entitlement on the flow of taxes and benefits. The impact on the flow of taxes is relatively minor. However, postponing the early entitlement age to 64 would result in a reduction in benefit payouts. It would take fifteen or twenty years before the missed benefits are compensated for by higher subsequent benefit payments, thus working in the direction of reducing, at least for a time, the cash flow problems of the system. Table 16 shows the difference between a regime where the early entitlement age is increased and a regime where the earnings test is abolished and is the difference between the entries in Table 15 and the corresponding entries in Table 10. Positive numbers indicate that the values for the increase in the early entitlement age exceed algebraically the values for the elimination of the earnings test. The table indicates that at ages in the early to mid sixties, the benefits under the elimination of the earnings test are much higher than those under the increase in the early entitlement age. The situation is reversed thereafter, but the early extra benefits under the earnings test elimination scenario are not offset by reduced later benefits until respondents reach their eighties.

\section{Conclusions.}

For persons between the early entitlement and full retirement age, the earnings test is actuarially fair, or better than fair, in that later benefits are increased so as to more than compensate for lost benefits from earnings over the annual exempt amount. Consequently, a prediction of life cycle models with perfectly operating capital markets is that the earnings test should not affect retirement behavior. We have found that because a number of people have 
high rates of time preference, even though their benefits are restored at what appears to be an actuarially fair rate, this restoration is actuarially fair only for those who are trading off current against future consumption at the same interest rate used by the government in its calculations.

From age 62 through the full retirement age, the earnings test reduces the share of married men who work full time by about four percentage points, which entails a reduction of about ten percent in the number of married men of that age at full time work. In terms of the cash flow of the system, abolishing the earnings test would have an adverse effect, at least initially. If the earnings test were abolished between the early and full retirement ages, the share of married men claiming Social Security benefits would increase by about 10 percentage points, and the average benefit payments would increase by about $\$ 1,800$ per recipient. The initial increase in benefit payments would eventually be reversed, over a time span of decades, because the annual benefit amounts would eventually be reduced by more than an actuarially fair amount due to the earlier collection of benefits.

As an alternative to increasing work effort by abolishing the earnings test, one can increase the employment of older persons by increasing the early entitlement age under Social Security. A major difference on the funding side is that abolishing the earning test results in an earlier flow of benefit payments from Social Security, worsening the cash flow problems of the system, while increasing the early entitlement age delays the flow of benefit payments from the system, improving its cash flow. 


\section{References}

Burtless, Gary and Robert Moffitt. 1984. "The Joint Choice of Retirement Age and Postretirement Hours of Work.” Journal of Labor Economics 3(2): 209-236.

Coile, Courtney, Peter Diamond, Jonathan Gruber and Alain Jousten. 2002. "Delays in claiming Social Security benefits". Journal of Public Economics 84: 357-385.

Disney, Richard and Sarah Smith. 2002. "The Labor Supply Effects of the Abolition of the Earnings Rule for Older Workers in the United States". The Economic Journal 112: C136C152.

Feldstein, Martin and Andrew Samwick. 1992. "Social Security Rules and Marginal Tax Rates". National Tax Journal 45: 1-22.

Friedberg, Leora. 2000. "The Labor Supply Effects of the Social Security Earnings Test." The Review of Economics and Statistics 82 (1): 48-63.

Gordon, Roger H. and Alan S. Blinder. 1980. "Market Wages, Reservation Wages and Retirement". Journal of Public Economics 14: 277-308.

Gruber, Jonathan and Peter Orszag. 1999. "What to Do About the Social Security Earnings Test? Issue Brief. Center for Retirement Research at Boston College. July.

Gustman, Alan L. and Thomas L. Steinmeier. 1985. "The 1983 Social Security Reforms and Labor Supply Adjustments of Older Individuals in the Long Run". Journal of Labor Economics 3(2): 237-253.

Working Paper 9404, December. 2002. "Retirement and the Stock Market Bubble". NBER . 2003. "Retirement Effects of Proposals by the President's Commission to Strengthen Social Security". NBER Working Paper 10030, October. Forthcoming, National Tax Journal. . 2004a. "The Social Security Early Entitlement Age In A Structural Model of Retirement and Wealth". Journal of Public Economics. . 2004b. "Social Security, Pensions and Retirement Behavior Within the Family". Journal of Applied Econometrics. . 2004c. "Personal Accounts and Family Retirement". NBER

Working Paper 10305. February.

Olson, Janice A. 1999. "Who is "62 Enough"? Identifying Respondents Eligible for Social Security Early Retirement Benefits in the Health and Retirement Study". Social Security Bulletin 62(3): 51-56.

Samwick, Andrew. 1998. "Discount Rate Heterogeneity and Social Security Reform". Journal of Development Economics 57: 117-146.

Song, Jae G. 2002. "Evaluating the Effects of the Removal of the Retirement Earnings Test in 2000". Mimeo. Social Security Administration. November.

Tran, Bac V.. 2002. "The Effect of the Repeal of the Retirement Earnings Test on the Labor Supply of Older Workers". Xeorx. University of Maryland at College Park. November. Trustees Report. 2003. The 2003 Annual Report of the Board of Trustees of the Old Age Survivors Insurance and Disability Insurance Trust Funds. Washington, D.C.. 
Table 1

Distribution of Observations Around Earnings Test Limit

(Percentage of observations reported in cells)

\begin{tabular}{|c|c|c|c|c|c|c|c|c|c|c|c|c|c|}
\hline Age & $<50 \%$ & $\begin{array}{c}50- \\
60 \%\end{array}$ & $\begin{array}{c}60- \\
70 \%\end{array}$ & $\begin{array}{c}70- \\
80 \%\end{array}$ & $\begin{array}{l}80- \\
90 \%\end{array}$ & $\begin{array}{c}90- \\
100 \%\end{array}$ & $\begin{array}{l}100- \\
110 \%\end{array}$ & $\begin{array}{c}110- \\
120 \%\end{array}$ & $\begin{array}{c}120- \\
130 \%\end{array}$ & $\begin{array}{c}130- \\
140 \%\end{array}$ & $\begin{array}{c}140- \\
150 \%\end{array}$ & $>150 \%$ & All \\
\hline Range & \multicolumn{13}{|c|}{ All observations with wage earnings } \\
\hline $62-69$ & $14.0 \%$ & 3.7 & 3.3 & 3.3 & 3.7 & 4.2 & 3.0 & 2.5 & 2.5 & 1.5 & 2.2 & 56.0 & $100 \%$ \\
\hline $62-64$ & 10.5 & 3.1 & 2.6 & 3.1 & 3.0 & 4.0 & 2.8 & 2.5 & 2.5 & 1.7 & 2.4 & 61.8 & 100 \\
\hline $65-69$ & 27.7 & 5.9 & 6.2 & 4.0 & 6.3 & 5.0 & 3.7 & 2.3 & 2.9 & 0.9 & 1.3 & 33.6 & 100 \\
\hline \multicolumn{14}{|c|}{ Partially retired workers } \\
\hline $62-69$ & 32.5 & 8.8 & 7.8 & 7.1 & 7.2 & 7.2 & 4.2 & 2.9 & 2.5 & 1.7 & 1.3 & 16.6 & 100 \\
\hline $62-64$ & 26.9 & 8.3 & 6.7 & 8.3 & 6.7 & 8.3 & 5.2 & 3.2 & 3.1 & 2.1 & 1.7 & 19.4 & 100 \\
\hline $65-69$ & 46.4 & 10.1 & 10.3 & 4.4 & 8.3 & 4.6 & 1.8 & 2.2 & 1.1 & 0.7 & 0.4 & 9.8 & 100 \\
\hline \multicolumn{14}{|c|}{ Full-time workers } \\
\hline $62-69$ & 1.9 & 0.6 & 0.7 & 1.1 & 1.7 & 2.5 & 2.3 & 2.2 & 2.6 & 1.5 & 2.7 & 80.2 & 100 \\
\hline $62-64$ & 1.4 & 0.4 & 0.5 & 0.6 & 1.2 & 1.9 & 1.6 & 2.2 & 2.2 & 1.5 & 2.8 & 83.6 & 100 \\
\hline $65-69$ & 4.6 & 1.4 & 1.9 & 3.8 & 4.6 & 5.8 & 6.0 & 2.4 & 4.8 & 1.2 & 2.4 & 61.2 & 100 \\
\hline
\end{tabular}


Table 2

Percentages Working Full-Time by Age and Year

$\begin{array}{ccccccc}\text { Age } & 1996 & 1998 & 2000 & 2002 & \begin{array}{c}2002-1998 \\ \text { Difference }\end{array} & \begin{array}{c}2002 / 1998 \\ \text { Ratio }\end{array} \\ 62 & 28.7 \% & 29.4 \% & 32.4 \% & 32.7 \% & 3.3 \% & 1.11 \\ 63 & 25.3 & 25.8 & 28.1 & 27.5 & 1.7 & 1.07 \\ 64 & 21.2 & 21.9 & 23.2 & 25.3 & 3.4 & 1.16 \\ 65 & 14.2 & 16.2 & 18.8 & 20.7 & 4.5 & 1.28 \\ 66 & 13.7 & 14.0 & 13.7 & 16.4 & 2.4 & 1.17 \\ 67 & 15.2 & 11.4 & 11.5 & 13.9 & 2.5 & 1.22 \\ 68 & 10.6 & 10.3 & 10.8 & 12.2 & 1.9 & 1.18 \\ 69 & 9.4 & 9.3 & 8.8 & 10.3 & 1.0 & 1.11\end{array}$


Table 3

Social Security Benefit Receipt by Age and Retirement Status, 1994 to 2002

\begin{tabular}{|c|c|c|c|c|c|}
\hline Age & $\begin{array}{c}\text { Retirees from } \\
\text { Full Time } \\
\text { Work }\end{array}$ & Fully Retired & $\begin{array}{l}\text { Partially } \\
\text { Retired }\end{array}$ & $\begin{array}{l}\text { Full-Time } \\
\text { Working }\end{array}$ & All \\
\hline \multicolumn{6}{|c|}{ Males } \\
\hline 62 & 72.0 & 75.1 & 60.8 & 9.8 & 47.5 \\
\hline 63 & 83.7 & 86.5 & 73.1 & 17.3 & 61.7 \\
\hline 64 & 86.1 & 87.3 & 80.9 & 24.6 & 68.4 \\
\hline 65 & 92.2 & 91.9 & 93.5 & 59.9 & 84.6 \\
\hline 66 & 92.9 & 93.0 & 92.6 & 74.8 & 89.4 \\
\hline 67 & 95.4 & 94.7 & 98.1 & 76.6 & 92.0 \\
\hline 68 & 92.7 & 93.6 & 89.1 & 79.1 & 91.1 \\
\hline 69 & 94.4 & 95.2 & 90.8 & 81.7 & 93.1 \\
\hline
\end{tabular}

Females

$\begin{array}{llllll}62 & 67.6 & 68.6 & 63.4 & 14.9 & 55.0 \\ 63 & 79.6 & 80.6 & 75.2 & 23.4 & 67.8 \\ 64 & 83.2 & 83.4 & 82.7 & 34.8 & 74.8 \\ 65 & 90.5 & 90.6 & 90.0 & 63.4 & 87.2 \\ 66 & 93.3 & 93.3 & 93.8 & 85.0 & 92.3 \\ 67 & 92.7 & 92.0 & 97.1 & 84.4 & 91.9 \\ 68 & 94.0 & 93.4 & 98.7 & 92.3 & 93.3 \\ 69 & 93.8 & 93.5 & 96.1 & 84.8 & 93.1\end{array}$

Observations for 1992 were excluded because unlike the questions in later years, the 1992 question on Social Security benefit receipt referred to receipt in the previous year. 
Table 4

Observed Retirement Percentages Among Married Males in HRS Data

\begin{tabular}{|c|c|c|c|c|c|}
\hline \multirow[b]{2}{*}{ Age } & \multicolumn{2}{|c|}{ Percentage Retiring } & \multicolumn{2}{|c|}{ Percentage Retired } & \multirow[b]{2}{*}{$\begin{array}{l}\text { Number of } \\
\text { Observations }\end{array}$} \\
\hline & $\begin{array}{l}\text { From Full } \\
\text { Time Work }\end{array}$ & Completely & $\begin{array}{l}\text { From Full } \\
\text { Time Work }\end{array}$ & Completely & \\
\hline 50 & 4.1 & 3.3 & 4.1 & 3.3 & 243 \\
\hline 51 & 0.9 & 0.0 & 5.0 & 3.3 & 361 \\
\hline 52 & 2.7 & 2.2 & 7.6 & 5.5 & 510 \\
\hline 53 & 2.0 & 1.1 & 9.7 & 6.6 & 621 \\
\hline 54 & 2.1 & 1.3 & 11.8 & 7.9 & 712 \\
\hline 55 & 3.1 & 2.7 & 14.9 & 10.6 & 801 \\
\hline 56 & 1.9 & 2.1 & 16.8 & 12.7 & 907 \\
\hline 57 & 4.0 & 3.2 & 20.8 & 15.9 & 990 \\
\hline 58 & 3.0 & 2.1 & 23.8 & 18.0 & 1064 \\
\hline 59 & 3.6 & 2.1 & 27.4 & 20.1 & 1132 \\
\hline 60 & 6.0 & 6.4 & 33.4 & 26.4 & 1121 \\
\hline 61 & 6.3 & 5.5 & 39.7 & 31.9 & 1043 \\
\hline 62 & 15.1 & 12.5 & 54.8 & 44.4 & 986 \\
\hline 63 & 5.6 & 3.4 & 60.4 & 47.9 & 909 \\
\hline 64 & 6.7 & 6.7 & 67.1 & 54.6 & 843 \\
\hline 65 & 9.1 & 6.7 & 76.2 & 61.3 & 744 \\
\hline 66 & 4.5 & 3.9 & 80.7 & 65.2 & 658 \\
\hline 67 & 2.8 & 2.9 & 83.5 & 68.1 & 565 \\
\hline 68 & 3.1 & 3.3 & 86.7 & 71.4 & 472 \\
\hline 69 & 1.7 & 4.6 & 88.4 & 76.0 & 379 \\
\hline
\end{tabular}

Total number of observed respondents: 2231 
Table 5

Estimated Parameters

\begin{tabular}{|c|c|c|c|}
\hline Symbol & Description & $\begin{array}{c}\text { Coefficient } \\
\text { Value }\end{array}$ & t-statistic \\
\hline \multirow[t]{2}{*}{$\alpha$} & Consumption parameter & -0.38 & 4.68 \\
\hline & Parameters in $\beta$ & & \\
\hline$\beta_{0}$ & Constant & -10.36 & 166.78 \\
\hline$\beta_{\mathrm{a}}$ & Coefficient of $\mathrm{Age}^{\mathrm{a}}$ & 0.091 & 4.22 \\
\hline$\beta_{\mathrm{h}}$ & Coefficient of Health ${ }^{b}$ & 4.14 & 4.61 \\
\hline \multirow[t]{2}{*}{$\beta_{\mathrm{c}}$} & Coefficient of Cohort ${ }^{\mathrm{b}, \mathrm{c}}$ Year of Birth) & 0.08 & 0.81 \\
\hline & Parameters in $\delta$ & & \\
\hline$\delta_{0}$ & Constant & -3.73 & 6.27 \\
\hline$\delta_{\mathrm{a}}$ & Coefficient of Age $\mathrm{e}^{\mathrm{b}, \mathrm{d}}$ & 0.55 & 2.98 \\
\hline \multirow[t]{3}{*}{$\sigma_{\varepsilon}$} & Standard Deviation of $\varepsilon$ & 5.33 & 9.35 \\
\hline & q value & \multicolumn{2}{|c|}{57.247} \\
\hline & Number of observations & \multicolumn{2}{|c|}{2231} \\
\hline
\end{tabular}

Several variables are differenced from their approximate means in the sample in order to facilitate estimation. They are:

a The actual variable is age -62 .

b These coefficients are all relative to the age coefficient, again to facilitate estimation.

c The actual variable is cohort - 1936 .

$\mathrm{d}$ The actual variable is age -65 . 
Table 6

Baseline Simulations of Retirement Outcomes for Married Men (Assuming the Earnings Test Is in Place and People Optimally Apply for Benefits)

\begin{tabular}{|c|c|c|c|c|}
\hline \multirow[b]{2}{*}{ Age } & \multicolumn{2}{|c|}{ Percentage Retiring } & \multicolumn{2}{|c|}{ Percentage Retired } \\
\hline & $\begin{array}{l}\text { From Full } \\
\text { Time Work }\end{array}$ & Completely & $\begin{array}{c}\text { From Full } \\
\text { Time Work }\end{array}$ & Completely \\
\hline 50 & 3.5 & 1.9 & 3.5 & 1.9 \\
\hline 51 & 1.3 & 0.7 & 4.8 & 2.7 \\
\hline 52 & 1.6 & 1.0 & 6.4 & 3.6 \\
\hline 53 & 1.6 & 1.1 & 8.0 & 4.7 \\
\hline 54 & 2.1 & 1.5 & 10.1 & 6.1 \\
\hline 55 & 3.5 & 2.3 & 13.6 & 8.4 \\
\hline 56 & 3.1 & 2.2 & 16.8 & 10.7 \\
\hline 57 & 3.6 & 2.7 & 20.4 & 13.4 \\
\hline 58 & 4.1 & 3.2 & 24.5 & 16.6 \\
\hline 59 & 4.5 & 3.4 & 29.1 & 20.0 \\
\hline 60 & 6.5 & 5.1 & 35.5 & 25.1 \\
\hline 61 & 5.5 & 4.5 & 41.0 & 29.6 \\
\hline 62 & 13.1 & 9.4 & 54.1 & 38.9 \\
\hline 63 & 5.8 & 4.9 & 59.9 & 43.8 \\
\hline 64 & 5.6 & 5.2 & 65.5 & 49.1 \\
\hline 65 & 5.9 & 5.6 & 71.4 & 54.7 \\
\hline 66 & 4.2 & 4.3 & 75.7 & 59.0 \\
\hline 67 & 4.1 & 4.5 & 79.7 & 63.4 \\
\hline 68 & 3.5 & 3.8 & 83.3 & 67.2 \\
\hline 69 & 3.1 & 3.4 & 86.4 & 70.6 \\
\hline
\end{tabular}

Percent of simulated retirements into partial retirement: 28.6 
Table 7

Baseline Projections of the Percent of Married Men Collecting Social Security Benefits (Assuming the Earnings Test Is in Place and People Optimally Apply for Benefits)

\begin{tabular}{|c|c|c|c|c|c|}
\hline \multirow[b]{2}{*}{ Age } & \multicolumn{4}{|c|}{ Percent Collecting Social Security } & \multirow[b]{2}{*}{ All } \\
\hline & $\begin{array}{l}\text { Retirees } \\
\text { From Full- } \\
\text { Time Work }\end{array}$ & $\begin{array}{c}\text { Completely } \\
\text { Retired }\end{array}$ & $\begin{array}{c}\text { Partially } \\
\text { Retired }\end{array}$ & $\begin{array}{l}\text { Full-Time } \\
\text { Work }\end{array}$ & \\
\hline 62 & 59.9 & 53.5 & 76.4 & 19.4 & 41.3 \\
\hline 63 & 65.1 & 60.0 & 79.0 & 22.7 & 48.1 \\
\hline 64 & 77.1 & 74.8 & 84.0 & 27.8 & 60.1 \\
\hline 65 & 92.3 & 92.0 & 93.3 & 65.8 & 84.7 \\
\hline 66 & 94.8 & 94.4 & 96.1 & 79.2 & 91.0 \\
\hline 67 & 97.2 & 97.1 & 97.7 & 87.0 & 95.2 \\
\hline 68 & 98.5 & 98.4 & 98.7 & 92.3 & 97.4 \\
\hline 69 & 99.2 & 99.1 & 99.2 & 94.7 & 98.5 \\
\hline
\end{tabular}


Table 8

Differences in Retirement Outcomes Between Simulations After Eliminating the Earnings Test and Simulations with the Earnings Test

\begin{tabular}{|c|c|c|c|c|}
\hline \multirow[b]{2}{*}{ Age } & \multicolumn{2}{|c|}{ Percentage Retiring } & \multicolumn{2}{|c|}{ Percentage Retired } \\
\hline & $\begin{array}{l}\text { From Full } \\
\text { Time Work }\end{array}$ & Completely & $\begin{array}{l}\text { From Full } \\
\text { Time Work }\end{array}$ & Completely \\
\hline 60 & 0.0 & 0.0 & 0.0 & -0.1 \\
\hline 61 & 0.0 & 0.0 & -0.1 & -0.1 \\
\hline 62 & -3.8 & -1.3 & -3.9 & -1.3 \\
\hline 63 & -0.3 & 0 & -4.2 & -1.3 \\
\hline 64 & -0.1 & -0.2 & -4.3 & -1.6 \\
\hline 65 & 0.1 & -0.1 & -4.2 & -1.7 \\
\hline 66 & 0.8 & 0.3 & -3.5 & -1.4 \\
\hline 67 & 0.5 & 0 & -2.9 & -1.3 \\
\hline 68 & 0.5 & 0.1 & -2.5 & -1.2 \\
\hline 69 & 0.4 & 0.1 & -2.2 & -1.1 \\
\hline
\end{tabular}

Table 9

Differences in Percent Collecting Social Security Benefits Between Simulations After Eliminating the Earnings Test and Simulations with the Earnings Test

Differences in Percent Collecting Social Security

$\begin{array}{cccccc}\text { Age } & \begin{array}{c}\text { Retirees } \\ \text { From Full- } \\ \text { Time Work }\end{array} & \begin{array}{c}\text { Completely } \\ \text { Retired }\end{array} & \begin{array}{c}\text { Partially } \\ \text { Retired }\end{array} & \begin{array}{c}\text { Full-Time } \\ \text { Work }\end{array} & \text { All } \\ 62 & -2.1 & -1.5 & -1.3 & 26.2 & 10.5 \\ 63 & -1.6 & -1.0 & -0.8 & 30.8 & 11.0 \\ 64 & -0.5 & -0.8 & 1.6 & 40.2 & 13.2 \\ 65 & 0.3 & -0.1 & 1.9 & 22.4 & 6.4 \\ 66 & 0.0 & -0.1 & 0.9 & 12.9 & 3.1 \\ 67 & 0.2 & 0.0 & 0.8 & 9.1 & 1.9 \\ 68 & 0.1 & 0.1 & 0.6 & 6.4 & 0.8 \\ 69 & 0.0 & 0.1 & 0.3 & 4.8 & \end{array}$


Table 10

Differences in Social Security Taxes and Benefits Between Simulations After Eliminating the Earnings Test and Simulations with the Earnings Test

$\begin{array}{ccc}\text { Age } & \text { Taxes } & \text { Benefits } \\ 50 & 0 & 4 \\ 55 & 3 & 34 \\ 60 & 2 & 98 \\ 61 & 3 & 161 \\ 62 & 84 & 1487 \\ 63 & 90 & 1813 \\ 64 & 101 & 2322 \\ 65 & 111 & 1722 \\ 66 & 90 & 1020 \\ 67 & 79 & 674 \\ 68 & 67 & 310 \\ 69 & 57 & -80 \\ 70 & & -503 \\ 75 & & -809 \\ 80 & & -750 \\ 85 & & -574 \\ 90 & & -380 \\ 95 & & -210\end{array}$


Table 11

Effect on Retirement of Increasing the Early Entitlement Age to 64

\begin{tabular}{|c|c|c|c|c|}
\hline \multirow[b]{2}{*}{ Age } & \multicolumn{2}{|c|}{ Percentage Retiring } & \multicolumn{2}{|c|}{ Percentage Retired } \\
\hline & $\begin{array}{l}\text { From Full } \\
\text { Time Work }\end{array}$ & Completely & $\begin{array}{l}\text { From Full } \\
\text { Time Work }\end{array}$ & Completely \\
\hline 58 & -0.1 & -0.1 & -0.2 & -0.3 \\
\hline 59 & -0.1 & -0.1 & -0.3 & -0.3 \\
\hline 60 & -0.2 & -0.2 & -0.4 & -0.5 \\
\hline 61 & -0.4 & -0.4 & -0.8 & -0.8 \\
\hline 62 & -6.5 & -4.1 & -7.3 & -4.8 \\
\hline 63 & -0.5 & -0.4 & -7.8 & -5.2 \\
\hline 64 & 7.3 & 5.1 & -0.6 & -0.2 \\
\hline 65 & 0.2 & 0.1 & -0.4 & -0.1 \\
\hline 66 & 0.2 & 0.2 & -0.3 & 0.1 \\
\hline 67 & 0.2 & 0.2 & 0.0 & 0.3 \\
\hline 68 & 0.2 & 0.2 & 0.1 & 0.5 \\
\hline 69 & 0.1 & 0.2 & 0.2 & 0.7 \\
\hline
\end{tabular}


Table 12

Difference in Retirement Outcomes Between Regime with Age 64 Early Entitlement and Regime with No Earnings Test

\begin{tabular}{ccccc} 
& \multicolumn{2}{c}{$\begin{array}{c}\text { Percentage Retiring } \\
\text { From Full } \\
\text { Time Work }\end{array}$} & Completely & \multicolumn{2}{c}{$\begin{array}{c}\text { Percentage Retired } \\
\text { From Full } \\
\text { Time Work }\end{array}$} & $\begin{array}{c}\text { Completely } \\
\text { Time }\end{array}$ & & & -0.2 & -0.2 \\
58 & -0.1 & -0.1 & -0.2 & -0.2 \\
59 & -0.1 & -0.1 & -0.4 & -0.4 \\
60 & -0.2 & -0.2 & -0.7 & -0.7 \\
61 & -0.4 & -0.4 & -3.4 & -3.5 \\
62 & -2.7 & -2.8 & -3.6 & -3.9 \\
63 & -0.2 & -0.4 & 3.7 & 1.4 \\
64 & 7.4 & 5.3 & 3.8 & 1.6 \\
65 & 0.1 & 0.2 & 3.2 & 1.5 \\
66 & -0.6 & -0.1 & 2.9 & 1.6 \\
67 & -0.3 & 0.2 & 2.6 & 1.7 \\
68 & -0.3 & 0.1 & 2.4 & 1.8 \\
69 & -0.3 & 0.1 & &
\end{tabular}


Table 13

Effect on Benefit Claiming of Increasing the Early Entitlement Age to 64

\begin{tabular}{cccccc} 
Age & \multicolumn{6}{c}{ Differences in Percent Collecting Social Security } \\
Retirees & $\begin{array}{c}\text { Fompletely Full- } \\
\text { Time Work }\end{array}$ & $\begin{array}{c}\text { Comtially } \\
\text { Retired }\end{array}$ & $\begin{array}{c}\text { Full-Time } \\
\text { Retired }\end{array}$ & Work \\
62 & -59.9 & -53.5 & -76.4 & -19.4 & -41.3 \\
63 & -65.1 & -60.0 & -79.0 & -22.7 & -48.1 \\
64 & -0.6 & -0.6 & -0.6 & 0.7 & -0.5 \\
65 & -0.2 & -0.2 & -0.3 & 0.5 & -0.1 \\
66 & -0.1 & -0.1 & -0.3 & 0.1 & -0.1 \\
67 & -0.1 & -0.1 & -0.1 & 0.0 & -0.1 \\
68 & 0.0 & 0.0 & 0.0 & -0.2 & 0.0 \\
69 & 0.0 & 0.0 & 0.0 & -0.2 & 0.0
\end{tabular}

Table 14

Difference in Benefit Claiming Between a Regime with Age 64 Early Entitlement and a Regime with No Earnings Test

\begin{tabular}{cccccc}
\multicolumn{6}{c}{ Differences in Percent Collecting Social Security } \\
Age & $\begin{array}{c}\text { Retirees } \\
\text { From Full- } \\
\text { Time Work }\end{array}$ & $\begin{array}{c}\text { Completely } \\
\text { Retired }\end{array}$ & $\begin{array}{c}\text { Partially } \\
\text { Retired }\end{array}$ & $\begin{array}{c}\text { Full-Time } \\
\text { Work }\end{array}$ & All \\
62 & -57.8 & -52.0 & -75.1 & -45.6 & -51.8 \\
63 & -63.5 & -59.0 & -78.2 & -53.5 & -59.1 \\
64 & -0.1 & 0.2 & -2.2 & -39.5 & -13.7 \\
65 & -0.5 & -0.1 & -2.2 & -21.9 & -6.5 \\
66 & -0.1 & 0.0 & -1.2 & -12.8 & -3.2 \\
67 & -0.3 & -0.1 & -0.9 & -9.1 & -2.0 \\
68 & -0.1 & -0.1 & -0.6 & -6.6 & -1.2 \\
69 & 0 & -0.1 & -0.3 & -5.0 & -0.8
\end{tabular}


Table 15

Effect on Social Security Taxes and Benefits Claiming of Increasing the Early Entitlement Age to 64

$\begin{array}{ccc}\text { Age } & \text { Taxes } & \text { Benefits } \\ 50 & 0 & -5 \\ 55 & 1 & -42 \\ 60 & 13 & -175 \\ 61 & 23 & -313 \\ 62 & 166 & -2738 \\ 63 & 176 & -3532 \\ 64 & 10 & -529 \\ 65 & 6 & -502 \\ 66 & 2 & -436 \\ 67 & -3 & -82 \\ 68 & -8 & 249 \\ 69 & -10 & 433 \\ 70 & & 545 \\ 75 & & 825 \\ 80 & & 774 \\ 85 & & 609 \\ 90 & & 420 \\ 95 & & 239\end{array}$


Table 16

Difference in Social Security Taxes and Benefits Between a Regime with Age 64 Early Entitlement and A Regime with No Earnings Test

$\begin{array}{ccc}\text { Age } & \text { Taxes } & \text { Benefits } \\ 50 & 0 & -9 \\ 55 & -2 & -76 \\ 60 & 11 & -273 \\ 61 & 20 & -474 \\ 62 & 82 & -4225 \\ 63 & 86 & -5345 \\ 64 & -91 & -2851 \\ 65 & -105 & -2224 \\ 66 & -88 & -1456 \\ 67 & -82 & -756 \\ 68 & -75 & -61 \\ 69 & -67 & 513 \\ 70 & & 1048 \\ 75 & & 1634 \\ 80 & & 1524 \\ 85 & & 1183 \\ 90 & & 800 \\ 95 & & 449\end{array}$


Appendix Table 1

Reasons for Deletions from Sample

Reason

Total sample individuals

Not specified gender

Not specified marital status

Spouse not interviewed if married

Not a career worker

Ambiguity about whether jobs are ss covered

No FT earnings in ss record or self report

No sr earnings, and ss earnings over limit

Relatively large business assets

No Pension Provider record in last job

FT years unavailable for spouse
Observations

Deleted

6785

1578

133

497

49

36

31

291

865

156
Observations

Left

12652

5867

4289

4156

3659

3610

3574

3543

3252

2387

2231 